\title{
Plant Growth Promoting Bacteria Isolated From a Mexican Natural Ecosystem Induce Water Stress Resistance in Maize and Sorghum Plants
}

Juan G Colli Mull1, Gustavo A de la Riva de la Riva ${ }^{1 *}$, Coczy D Vargas-Sámano, Gisselle Pérez-Machado² and Guillermin Agüero-Chapin,4

${ }^{1}$ Departamento de Biología, Instituto Tecnológico Superior de Irapuato (ITESI), Carretera Irapuato-Silao Km 12.5, Colonia El Copal, Irapuato, Guanajuato, México

${ }^{2}$ Departamento de Fisiología, Facultad de Medicina y Odontología, Universidad de Valencia, Ave. Blasco Ibañez 46010, Valencia, España

${ }^{3}$ CIIMAR/CIMAR, Interdisciplinary Centre of Marine and Environmental Research, University of Porto, Terminal de Cruzeiros do Porto de Leixões, Av. General Norton de

Matos, s/n, Porto 4450-208, Portugal

${ }^{4}$ Biology Department, Faculty of Sciences, University of Porto, Rua do Campo Alegre, s/n, Porto 4169-007, Portugal

\begin{abstract}
The negative environmental impact due to the excessive use of chemical products on agricultural crops is mitigated byusing plant growth-promoting microorganisms, including bacteria and beneficial fungi associated to plant roots. Microorganisms could play a significant role in this respect due to their genetic diversity, ubiquity, interaction with crop plants and properties of tolerance to extremities. Therefore the microbial biodiversity and its effect on soil quality; soil nutrient cycling; plant growth promotion is considered a hub of attention for bio prospection studies as an alternative to favor sustainable agriculture. The biodiversity of bacteria were deciphered from different sites in "Sierra Gorda" highlands, considered Reserve of Biosphere, in the download region of Central Mexico, known as Bajío. Culturable bacteria were isolated from soil rhizosphere samples and biochemically characterized due their indole-acetic acid (IAA) synthesis and 1-aminocyclopropane-1-carboxylate (ACC) deaminase activity, as well as siderophore and polyhydroxybutyrate productions, cellulase and chitinase activity and phosphate mobilization. Bacteria were identified by the amplification of the $16 \mathrm{~S}$ rRNA gene and BLAST analysis. Three strains, Pseudomonas variovencis XiU1297 and Luteibacter sp. XiU1292, Acinetobacter inoffii XiU12138 were selected to test their effects on the growth of Maize and Sorghum under water stress at greenhouse conditions. The results show differential growth promotion effect of those bacteria in maize and sorghum. The bacteria were selected to conform a consortium suitable to use in agriculture as biofertilizer.
\end{abstract}

Keywords: Soil bacteria; Plant growth; Water stress

\section{Introduction}

It's known that microbiota displays multiple properties influencing in plant development, soil productivity, biomass production and conservation of whole ecosystems [1-3]. Microorganisms play important roles in different biogeochemical cycles and in the mobilization, cycling and transformation of inorganic and organic chemical soil compounds. Soil microorganisms influence in structure fertility, plant health and nutrition [4-9]. Microbial biodiversity play an important role in conservation and restoration of ecosystems and it's also a source of microorganisms for biotechnology developments. In the soil, bacteria are the most abundant microorganisms particularly in the rizhosphere, where they are able to colonize plant roots. They get multiply and adapt to colonize all the ecological niches found on the roots at all stages of plant growth, in the presence of a competing microflora [10-12]. Bacterial soil communities, its biodiversity and the relative abundances of individual bacterial taxa have been examined extensively in many ecosystems over the past 30 years. However, few studies have been focused on biodiversity and growth rates of specific taxa in natural soil microbial communities. It has been known for some time that the soil hosts a large number of bacteria (often around $10^{8}$ to $10^{9}$ cells per gram of soil) but the number of culturable bacterial cells in soil is generally only about $1 \%$ out of the total number of cells present [13]. The most abundant bacterial genera in soil reported are, Azospirillum ssp., Alcaligenes ssp., Arthrobacte ssp., Acinetobacter ssp., Bacillus ssp., Burkholderia ssp., Erwinia ssp., Pseudomonas ssp., Rhizobium ssp., Rhodococcus ssp. and Streptomyces ssp. [14]. For the maintenance of bacterial communities in the soil, their members should have different related biochemical activities for nutrient cycling, biological control and plant growth promotion. Bacterial communities can be classified according to their effects on plants through the way they interact with roots. Some are pathogens whereas other triggers beneficial effects on plants such as, nitrogen fixing, auxins gibberellins and cytokinins [15-
18]. Others produce siderophores which are essential for aiding in the biocontrol of pathogens, promoting antifungal or supporting activities in the control of the deleterious effects of pathogens by producing inhibitory substances, excluding them from the roots by competition or by inducing systemic resistance [19-22]. Plant Growth Promoting Bacteria (PGPB) comprises free-living and those that form specific symbiotic relationships with plants (e.g. Rhizobia spp. and Frankia spp.), bacterial entophytes able to colonize a portion of a plant's interior tissues and cyanobacteria [23]. PGPB species of Pseudomonas sp. and Bacillus sp. can produce phytohormones or growth regulators inducing the formation of a greater amount of fine roots in crops and consequently, they increase absorptive surface of plant roots for uptake of water and nutrients [24]. PGPB release siderophores, low-molecular-weight compounds with high $\mathrm{Fe}^{3+}$ chelating affinity that may scavenge iron by formation of soluble $\mathrm{Fe}^{2+}$ complexes by active transport mechanisms of bacteria and plants. In addition acquisition of iron is also important for some pathogenic bacteria and therefore PGPB successfully compete for iron contributing to their reduction [25]. Significant increases on growth and yield of important crops in response to inoculation with PGPB have been reported [15]. Azospirillum, Pseudomonas

*Corresponding author: Gustavo A. de la Riva de la Riva. Departamento de Biología, Instituto Tecnológico Superior de Irapuato (ITESI), Carretera IrapuatoSilao Km 12.5, Colonia El Copal, Irapuato, Guanajuato, México. C.P. 36821 Phone and fax: 51-462-606-79-00; e-mail: gudelariva@itesi.edu.mx

Received September 12, 2017; Accepted September 25, 2017; Published October 02, 2017

Citation: Colli JG, de la Riva de la Riva GA, Vargas-Sámano CD, Pérez-Machado G Agüero-Chapin G (2017) Plant Growth Promoting Bacteria Isolated From a Mexican Natural Ecosystem Induce Water Stress Resistance in Maize and Sorghum Plants. J Microb Biochem Technol 9:209-219. doi: 10.4172/1948-5948.1000367

Copyright: @ 2017 Colli JG, et al. This is an open-access article distributed under the terms of the Creative Commons Attribution License, which permits unrestricted use, distribution, and reproduction in any medium, provided the original author and source are credited. 
Citation: Colli JG, de la Riva de la Riva GA, Vargas-Sámano CD, Pérez-Machado G, Agüero-Chapin G (2017) Plant Growth Promoting Bacteria Isolated From a Mexican Natural Ecosystem Induce Water Stress Resistance in Maize and Sorghum Plants. J Microb Biochem Technol 9:209-219. doi: 10.4172/1948-5948.1000367

and Azotobacter strains could influence germination and seedling growth $[26,27]$. It has been shown that wheat yield increased up to $30 \%$ after inoculation with Azotobacter sp. and up to $43 \%$ with Bacillus inoculation. Strains of Pseudomonas putida and Pseudomonas fluorescens could increase root and shoot elongation in canola, wheat and potato [28-31]. The download region of Central Mexico, known as Bajío, is an important region for biodiversity due its location in the confluence of Nearctic and Subtropical biogeographic regions. The intensive mining, agricultural and industrial activities impacted the ecology of the region, the use of fertilizer and other agrochemicals displaced the original micro biota. We started an extensive program of microbial prospection of Natural Protected Areas (NPAs) in the state of Guanajuato, Mexico. The state of Guanajuato has twenty-four NPAs categorized according to their biodiversity, territorial extension, economic and social development; those that fall in the mountains of Sierra Gorda are classified as biosphere reserves, zones of sustainable management, natural management zones and ecological park. For each zone, the management form may differ, but all are destined for ecological restoration and sustainable development. These areas are well preserved showing a high microbial diversity, which is very important for our bio prospection program that includes the study of microbial diversity and their potentiality to develop useful applications for soil, forest and ecological restoration providing positive implications in agriculture sustainability. In this work, we isolated cultivable microorganisms from soil and disclosed characteristics interesting for agricultural purposes such as growth stimulating factors, siderophore production, chitinase and cellulase activities, and polymer production. The isolated bacteria showing activities related to pest and pathogen biocontrol and plant growth promotion were biochemically and taxonomically characterized. Three strains, Pseudomonas variovencis XiU1297, Luteibacter sp. XiU1292 and Acinetobacter iwoffii XiU12138, were selected to test their effects on the growth of Maize and Sorghum under water stress and evaluated at greenhouse conditions. The results show positive but differential effects of those bacteria for each assayed crop.

\section{Materials and Methods}

\section{Soil samples and isolation}

Soil samples were taken from rhizosphere associated to Quercus ssp. forest at Natural Protected Area "Charco Azul", at 2,191 m upper the sea level (Xichú, Guanajuato, Mexico) in the Sierra Gorda Biosphere Reserve. Soil samples were collected from four replicates plots. The samples were taken within $3 \mathrm{~km}$ radius from the center of the base camp $\left(21^{\circ} 18^{\prime} 50.5^{\prime \prime} \mathrm{N} 100^{\circ} 06^{\prime} 39.2^{\prime \prime} \mathrm{W}\right)$. Soil samples were kept on ice and transferred to the laboratory and primary suspensions were extracted by adding $9 \mathrm{ml}$ of sterile $1 \mathrm{X}$ Phosphate Buffer Saline (PBS buffer: $8 \mathrm{~g} / \mathrm{L}$ $\mathrm{NaCl}, 0.2 \mathrm{~g} / \mathrm{L} \mathrm{KCL}, 0.2 \mathrm{~g} / \mathrm{L} \mathrm{KH}_{2} \mathrm{PO}_{4} 1.15 \mathrm{~g} / \mathrm{L} \mathrm{Na} \mathrm{HPO}_{4}$, $\mathrm{pH} 7.4$ ) to $1 \mathrm{~g}$ of each sample. The resulting suspensions were agitated during 48 hours at $100 \mathrm{rpm}$ at room temperature. Serial dilutions up to $1: 10^{8}$ of each primary suspension were prepared and $1 \mathrm{~mL}$ was plated on solid $\mathrm{LB}$ medium. These plates were then incubated at $30^{\circ} \mathrm{C}$ for $16-72$ $\mathrm{h}$ before the selection, classification and the phenotype/genotype identification process. Bacterial colonies were picked up and cultured in $5 \mathrm{~mL} \mathrm{LB}$ medium, grown for two days at $100 \mathrm{rpm}$ agitation and room temperature and conserved in glycerol. Each isolate was registered in the Institutional Tissue and Culture Collection(ITCC).

\section{Culture media}

Bacterial strains were isolated and cultured in liquid or solid LB medium ( $1 \%$ tryptone, $0.5 \%$ yeast extract, $1 \% \mathrm{NaCl} ; 1.5 \%$ agar).
Minimal Media MM9 medium (6.8 g/L Na $\mathrm{HPO}_{4}, 0,3 \mathrm{~g} / \mathrm{L} \mathrm{KH}_{2} \mathrm{PO}_{4}, 0.5$ $\mathrm{g} / \mathrm{L} \mathrm{NaCl}, 1 \mathrm{~g} / \mathrm{L} \mathrm{NH}_{4} \mathrm{Cl}$ and $0.2 \%$ glucose) was used to grow bacterial strains for chitinase, cellulase and siderophore assays and CAS-blue agar was also used in siderophore test [32]. The production of polyhidroxibutirate by bacterial isolates were tested using media M-PHB 1 $\left(20 \mathrm{~g} / \mathrm{L}\right.$ sucrose, $2 \mathrm{~g} / \mathrm{L}\left(\mathrm{NH}_{4}\right) \mathrm{SO}_{4}, 1 \mathrm{~g} / \mathrm{L} \mathrm{KH}_{2} \mathrm{PO}_{4}, 0.2 \mathrm{~g} / \mathrm{L} \mathrm{MgSO}_{4} .7 \mathrm{H}_{2} \mathrm{O}$, $0.02 \mathrm{~g} / \mathrm{L} \mathrm{CaCl}_{2} .2 \mathrm{H}_{2} \mathrm{O}, \mathrm{FeSO}_{4} .7 \mathrm{H}_{2} \mathrm{O} 0.01 \mathrm{~g} / \mathrm{L}$, agar $\left.15 \mathrm{~g} / \mathrm{L}, \mathrm{pH} 7.0\right)$ and M-PHB 2 (glucose $10 \mathrm{~g} / \mathrm{L}, \mathrm{MgSO}_{4}^{2} 7 \mathrm{H}_{2} \mathrm{O} 0.2 \mathrm{~g} / \mathrm{L}, \mathrm{CaCl}_{2} .2 \mathrm{H}_{2} \mathrm{O} 0.07 \mathrm{~g} / \mathrm{L}$, FeSO $7 \mathrm{H}_{2} \mathrm{O} 0.01 \mathrm{~g} / \mathrm{L}$, EDTA $0.01 \mathrm{~g} / \mathrm{L}, \mathrm{KH} \mathrm{PO} 0.6 \mathrm{~g} / \mathrm{L}, \mathrm{K} \mathrm{HPO} 0.9$ $\mathrm{g} / \mathrm{L}, \mathrm{pH} 7.0$ ). Sabouraud Dextrose Agar (SDA) medium ( $4 \%$ dextrose, $1 \%$ peptone and $2 \%$ agar), was used to growth test fungi Fusarium verticillioides, Fusarium solani and Rizoctonia solani.

\section{Gram staining}

The differentiation of bacteria into either the gram-positive or the gram-negative group we follow theprocedure described by farmer [33].

\section{Qualitative and quantitative indole-acetic acid production}

Screening of bacterial isolates for indole acetic acid (IAA) was done qualitative and quantitative. The ability of the strains to produce indole acetic acid (IAA) was tested according to the qualitative method reported by Sawar and Kremer [34]. Microorganism incubation was carried out for $72 \mathrm{~h}$ at $150 \mathrm{rpm}$ in complete darkness in the culture medium indicated. The $150 \mu \mathrm{L}$ of culture were distributed into $96-$ well plate followed by addition of $100 \mu \mathrm{L}$ of Sarkowsky reagent $(12 \mathrm{~g} / \mathrm{L}$ $\mathrm{FeCl}_{3}$ in $7.9 \mathrm{M} \mathrm{H}_{2} \mathrm{SO}_{4}$ ) with a 1:1 relation between the reagent and the supernatant from microorganism culture. The reaction lasted for 30 min in darkness to yield a pink colored product. Indolic compounds concentration was analyzed by spectrophotometry at $520 \mathrm{~nm}$. Serial dilutions prepared from Indole-3-acetic acid sodium salt (Sigma, USA) and used as IAA standard. The quantitative assays of IAA were carrying for selected strains using the same described conditions but with presence tryptophan at $0,50,150,300,500$ and $1000 \mu \mathrm{g} / \mathrm{ml}$. IAA concentration was measured in the spectrophotometer at $520 \mathrm{~nm}$ and quantified using an IAA standard. The experiments were done in triplicates and data were expressed as the mean value \pm standard error [35].

\section{DNA extraction and 16s rRNA amplification}

DNA was extracted from isolates by using a Microbial DNA extraction kit (MO BIO Laboratories Inc., Carlsbad, CA USA). The fragments of $16 \mathrm{~S}$ rRNA gene were amplified by using the primers RP1 (ccgaattcgtcgacaacAGAGTTTGATCCTGGCTCAG) and FD1 (ccgaattcgtcgacaacAGAGTTTGATCATGGCTCAG) [36]. The PCR conditions were determined as follows: pre-denaturing step at $95^{\circ} \mathrm{C}$ for $2 \mathrm{~min}$, denaturing at $94^{\circ} \mathrm{C}$ for $50 \mathrm{~s}$, annealing at $57^{\circ} \mathrm{C}$ for $50 \mathrm{~s}$, polymerization at $75^{\circ} \mathrm{C}$ for $2 \mathrm{~min}$ and post PCR at $75^{\circ} \mathrm{C}$ for $10 \mathrm{~min}$ and 35 cycles. PCR products were analyzed on $1 \%$ agarose gel and sequenced. Bacteria were identified by BLAST sequenced analysis of the amplified 16S rRNA genefragments.

\section{ACC deaminase activity}

ACC deaminase activity was evaluated by measuring of a-ketobutyrate and ammonia production when the ACC is cleavage by ACC deaminase $[37,38]$. The standard curve were obtained by serial dilutions of a-ketobutyrate at $0,0.01,0.05,0.1,0.2,0.5,0.75$ and 1 $\mathrm{mM}$ concentrations in $100 \mathrm{mM}$ Tris- $\mathrm{HCl} \mathrm{pH} 8.5$ (total Volume 500 $\mu \mathrm{l})$, mixed in each case with $400 \mu \mathrm{l}$ of $0.56 \mathrm{~N} \mathrm{HCl}$ and $150 \mu \mathrm{l} \mathrm{DNF}$ solution $(0.1 \mathrm{~g}$ 2,4dinitrophenylhydrazine, Sigma, USA; in $100 \mathrm{ml}$ of $2 \mathrm{~N} \mathrm{HCl}$ ) followed by addition of one $\mathrm{ml}$ of $2 \mathrm{~N} \mathrm{NaOH}$. Finally absorbance was determined at $540 \mathrm{~nm}$. The different strains were grown 
Citation: Colli JG, de la Riva de la Riva GA, Vargas-Sámano CD, Pérez-Machado G, Agüero-Chapin G (2017) Plant Growth Promoting Bacteria Isolated From a Mexican Natural Ecosystem Induce Water Stress Resistance in Maize and Sorghum Plants. J Microb Biochem Technol 9:209-219. doi: 10.4172/1948-5948.1000367

in $5 \mathrm{ml}$ of $\mathrm{LB}$ medium at $28^{\circ} \mathrm{C}$ until they reached stationary phase, The bacterial cells were collected by centrifugation, washed twice with $0.1 \mathrm{M}$ Tris- $\mathrm{HCl}$ ( $\mathrm{pH} 7.5$ ), suspended in $2 \mathrm{ml}$ of modified $\mathrm{M} 9$ minimal medium supplemented with $3 \mathrm{mM}$ final concentration of ACC without PEG for non-stress condition and with PEG 6000 $(-0.30 \mathrm{MPa})$ for drought stress condition and them incubated $28^{\circ} \mathrm{C}$ with shaking for additional 36-72 $\mathrm{h}$. The induced bacterial cells were collected by centrifugation ( $3000 \mathrm{rpm}$ for $5 \mathrm{~min}$ ), twice washed with $0.1 \mathrm{M}$ Tris- $\mathrm{HCl}$ ( $\mathrm{pH}$ 7.5) followed by centrifugation (3000 rpm for 5 min and finally resuspended in $200 \mu \mathrm{l}$ of $0.1 \mathrm{M}$ Tris- $\mathrm{HCl}$ ( $\mathrm{pH} 8.5$ ). The resuspended cells were labilized by adding $5 \%$ toluene $(\mathrm{v} / \mathrm{v})$ and mixed at the highest vortex speed for $30 \mathrm{~s}$. As positive control we used $50 \mu \mathrm{l}$ of cell suspension with $5 \mu \mathrm{l}$ of $0.3 \mathrm{M}$ ACC and as negative control we used $50 \mu \mathrm{l}$ of labilized bacterial cell suspension without ACC, incubated at $28^{\circ} \mathrm{C}$ for $30 \mathrm{~min}$. The blank included $50 \mu \mathrm{l}$ of $0.1 \mathrm{M}$ Tris- $\mathrm{HCl}(\mathrm{pH}$ 8.5) with $5 \mu \mathrm{l}$ of $0.3 \mathrm{M}$ ACC. The samples were then mixed with 500 $\mu \mathrm{l}$ of $0.56 \mathrm{~N} \mathrm{HCl}$ and the debris was removed by centrifugation at 12, $000 \mathrm{~g}$ for $5 \mathrm{~min}$. A $500 \mu \mathrm{l}$ aliquot of the supernatant was transferred to a glass test tube and mixed with $400 \mu \mathrm{l}$ of $0.56 \mathrm{~N} \mathrm{HCl}$ and $150 \mu \mathrm{l}$ of DNF solution ( $0.1 \mathrm{~g}$ 2,4-dinitrophenylhydrazine in $100 \mathrm{ml}$ of $2 \mathrm{~N} \mathrm{HCl})$; and the mixture was incubated at $28^{\circ} \mathrm{C}$ for $30 \mathrm{~min} .1 \mathrm{ml}$ of $2 \mathrm{~N} \mathrm{NaOH}$ was added to the sample before determining absorbance at $540 \mathrm{~nm}$. In each case the optical density of samples were compared with a standard curve previously established.

\section{Siderophores production analysis}

Siderophore production was analyzed on chrome azurol $\mathrm{S}$ agar plates [39]. Bacteria were grown for 2 weeks at room temperature on plates and siderophore producing organisms were able to extract iron from the blue $\mathrm{Fe}^{+3}$-CAS complex forming an orange depletion zone in the medium. The chromeazurol (CAS) agar assay was used according to the modifications introduced by Silva-Stenico et al. [40]. Positive colonies were identified by the formation of a clear halo around them, showing a visual change in color from dark blue to orange. In addition, antifungal activity was tested by diffusion method against Fusarium verticillioides, Fusarium solani and Rizoctonia solani on Sabouraud Dextrose Agar (SDA) medium [41]. Firstly the test fungi were grown in SDA medium until sporulation, diluted suspension of spore were taken and suspended in $10 \mathrm{ml}$ of sterile $1 \mathrm{X}$ PBS and number of CFU was counted. Then, $100 \mu \mathrm{l}$, of a $10^{5} \mathrm{CFU} / \mathrm{ml}$ were spread on SDA plates. Wells (diameter $10 \mathrm{~mm}$ ) were made into SDA plates and filled with $100 \mu \mathrm{l}$ of bacterial culture at concentration of $10^{8} \mathrm{CFU} / \mathrm{ml}$. LB liquid media with $100 \mu \mathrm{l}$ nystatin solution $(100 \mu \mathrm{g} / \mathrm{ml})$ was used as a positive control. The antifungal activity was evidenced when growth inhibition zone against test fungiappeared.

\section{Cellulase and chitinase activities}

For cellulase activity, we used carboxy-methyl-cellulose (CMC) in solid minimal media containing $0.01 \% \mathrm{MgSO}_{4} .7 \mathrm{H} \mathrm{O}, 0.01 \%$ $\mathrm{K}_{2} \mathrm{HPO}_{4}, 0.05 \%$ yeast extract, $0.7 \%\left(\mathrm{NH}_{4}\right)_{2} \mathrm{SO} 4,0.1 \% \mathrm{NaCl}^{2}$ and $1.5 \%$ bacteriological agar. CMC degradation by the isolates by covering the Petri dishes with Congo Red dye, as described by Teather and Wood [42]. CMC degradation was indicated by a clear zone around the colonies. For Chitinase activity, the strains were cultivated in medium contained of $1 \%$ chitin, $0.01 \%$ Congo Red, $0.01 \% \mathrm{MgSO} .7 \mathrm{H}$ O, $0.01 \%$ $\mathrm{K}_{2} \mathrm{HPO}_{4}, 0.05 \%$ yeast extract, $0.7 \%\left(\mathrm{NH}_{4}\right)_{2} \mathrm{SO}_{4}, 0.1 \% \mathrm{NaCl}^{2}$ and $1.5 \%$ bacteriological agar and were incubated at $37^{\circ} \mathrm{C}$ for five days. The isolates causing a clear zone were considered positive to this test [43].

\section{Phosphate-solubilizing assay}

The ability of isolates to solubilize phosphate was assessed qualitatively using potato-dextrose yeast agar (PDA, $\mathrm{pH}$ 7.0) supplemented with freshly precipitated $50 \mathrm{~mL} 10 \% \mathrm{~K}_{2} \mathrm{PO}_{4}$ plus and $100 \mathrm{~mL} 10 \% \mathrm{CaCl}_{2}$ per liter of PDA medium. Each bacterial culture was streaked in the center of PDA-Calcium phosphate plate and then incubated during two weeks at $27^{\circ} \mathrm{C}$. The clearing zone surrounding the developed bacterial colony shows phosphate solubilization [22].

\section{Polyhydroxybutyrate (PHB) detection}

Polyhydroxybutyrate (PHB) production was detected in bacterial isolates by growing it on Petri dishes containing Media 1 or Media 2 [44]. Isolates of axenic colonies were randomly picked and cultured in solid MM9 supplemented with 5 g glucose/L and $0.5 \mathrm{mg}$ Nile blue (Sigma, St. Louis, MO, USA). Petri dishes were incubated for 4-5 days at $30^{\circ} \mathrm{C}$. The orange fluorescence observed under UV $(\lambda=312 \mathrm{~nm})$ was used to detect $\mathrm{PHB}$ positive colonies in contrast with barely visible fluorescence of PHB-negative colonies. Standard were prepared from pure PHB (Sigma, USA) by modified method at concentrations ranging from 1 to $10 \mu \mathrm{g} / \mathrm{ml}[45,46]$. Comparing the fluorescence intensity in the halo generated by each isolates we grouped it in tree groups according to biopolymer production by named low (lower $3 \mathrm{ng} / \mathrm{ml}$ ), middle (between 3 and $6 \mu \mathrm{g} / \mathrm{ml}$ ) or high (between 6 to $10 \mu \mathrm{g} / \mathrm{ml}$ ).

\section{Effect of bacterial strains on plant growth in maize and sorghum}

Bacterial inoculum was prepared by growing cells in nutrient broth at $30^{\circ} \mathrm{C}, 120 \mathrm{rpm}$ until the end of the exponential growth phase. Bacteria were then harvested by centrifugation $(5000 \mathrm{rpm} / \mathrm{min}$ for $10 \mathrm{~min}$ ), washed and suspended in PBS to $10^{8} \mathrm{CFU} / \mathrm{ml}$. Germinated seed were inoculated with $1 \mathrm{~mL}$ of bacterial suspension and control seeds with $1 \mathrm{~mL}$ PBS into plastic pots filled with $200 \mathrm{~g}$ sterilized soil at final bacterial concentration of $5 \times 10^{5} \mathrm{CFU} / \mathrm{g}$ soil $\left(1 \mathrm{~mL}\right.$ of $10^{8}$ $\mathrm{CFU} / \mathrm{ml}: 200 \mathrm{~g}$ soil). The inoculated seedlings were cultured under greenhouse conditions with $14 \mathrm{~h} /$ day photoperiod at $28^{\circ} \mathrm{C}$ during the day, $20^{\circ} \mathrm{C}$ during the night and $60 \%$ relative humidity. All pot experiments contained five seedlings and five replicas were performed per pot. The plants were harvested after six weeks of inoculation and dry and fresh plant biomass were measured and compared to control plants (NC).

\section{Effect of bacterial strains on plant growth under water stress conditions}

We followed the method described by Mayak et al. to evaluate the effect of bacterial isolates on different plants crops maintained under greenhouse conditions [47]. Plants were cultivated in soil conditions similar to agricultural lands of Bajio region at greenhouse and were subjected to water stress at week 3 after germination. The irrigation was reassumed at the beginning of week 4 . The effects of bacterial treatments were measured after 3, 4, 5 and 6 weeks by calculating the relative water content (RWC). RWC was measured by comparing fresh weight (FW), fully turgid weight (FTW) and dry weight (DW). Firstly, FW was measured in collected plants; then they were conserved in humid camera at $25^{\circ} \mathrm{C}$ in the dark during $48 \mathrm{~h}$ to measure the FTW. Ones we determined FW and FTW, all the plants were dried during 
Citation: Colli JG, de la Riva de la Riva GA, Vargas-Sámano CD, Pérez-Machado G, Agüero-Chapin G (2017) Plant Growth Promoting Bacteria Isolated From a Mexican Natural Ecosystem Induce Water Stress Resistance in Maize and Sorghum Plants. J Microb Biochem Technol 9:209-219. doi: 10.4172/1948-5948.1000367

$6 \mathrm{~h}$ at $50^{\circ} \mathrm{C}$ and then weighed (DW). The RWC for each crops were determined as follows:

$$
\begin{array}{ll}
\mathbf{R W C}=\frac{\mathbf{F W}-\mathbf{D W}}{\mathbf{F T W}-\mathbf{D W}} & \text { FW }: \text { FreshWeight } \\
& \text { DW }: \text { DriedWeight } \\
& \text { FTW }: \text { Fully Turgid Water Weight }
\end{array}
$$

\section{Prevalence of the bacterial inoculants in plant rhizoosphere and bulksoil}

Besides the effect of inoculated bacterial strains on sorghum and maize under water stress conditions, we also explore the prevalence and dynamic of the inoculated strains. Rhizosphere and bulk soil samples were collected at the started day, and after 3, 4, 5 and 6 weeks. For each treatment and sampling time the roots (three plants per replicate) were analyzed to determine the population dynamic of the three bacterial strains during the water stress experiment. To quantify the number of UFC in soil and rhizosphere of both crops, three replicates per treatment were independently analyzed. For rhizosphere, adhering soil was removed and treated. The rest of the soil was well mixed and used for determination of bacterial persistence in bulk soil. For rhizosphere bacterial isolation, roots were washed with sterile tap water before microbial cells were extracted as follows: the roots were cut into pieces of approximately $1 \mathrm{~cm}$ length and carefully mixed. Five gram of roots was placed in sterile flash and shaker for $30 \mathrm{~s}$ at high speed after adding $15 \mathrm{ml}$ of sterile $0.3 \% \mathrm{NaCl}$. This step was repeated three times [48]. Aliquots of the each rhizosphere microbial cell suspension were immediately processed to determine CFU counts by plating serial dilutions onto LB agar media supplemented with antibiotic allowing the growth of inoculated bacteria but no other soil bacteria. The used antibiotics were selected previously as follows: as follows: Luteibacter sp. XiU1292 (Tetracycline $50 \mu \mathrm{g} / \mathrm{ml}$ ) Pseudomonas vranovencis XiU1297 (Cephalexin $30 \mu \mathrm{g} / \mathrm{ml}$ ) Acinetobacter iwoffi XiU12138 (Kanamycin $30 \mu \mathrm{g} / \mathrm{ml}$ ). The plates were incubated at $28^{\circ} \mathrm{C}$ for $48 \mathrm{~h}$ and the CFU counts were calculated per gram of root dry mass (RDM). In case of bulk soil, the $200 \mathrm{~g}$ of soil was mechanically homogenized and $1 \mathrm{~g}$ each sample was put in $9 \mathrm{ml}$ PBS buffer and shake for $48 \mathrm{~h}$ at $28^{\circ} \mathrm{C}$. Serial dilutions were seeded in LB medium supplemented with corresponding antibiotic as described above and incubated for $48 \mathrm{~h}$ at $28^{\circ} \mathrm{C}$. The inoculant densities (CFU counts/g soil) were calculated logarithmically $(\log 10)$ in each case.

\section{Statistical Analysis}

The effect of the selected bacterial strains on plant growth was measured in green house at two conditions: normal irrigation scheme and water stress conditions. Water stress experiments were evaluated by the calculation of RWC. The evaluation of selected bacterial strains on maize, sorghum was carried with five replicates. Data were analyzed by analysis of variance (ANOVA, p-level <0.05). The statistical analysis and graphic construction were performed using Minitab 16 (Minitab Inc. Minitab Acad. Software Center,Pennsylvania).

\section{Results}

\section{Bacterial isolation}

The soil samples used in this study was collected in selected prospective zone of "Charco Azul" NPA (Xichú, Guanajuato, Mexico) located in "Sierra Gorda Reserve of Biosphere" and bacterial colonies were grown, picked and cultured. About $3.5 \log ^{8} \mathrm{CFU} / \mathrm{g}$ were found in soil samples. Because of a large number of isolates, the strains were previously characterized by their morphological appearance (white, opaque of translucent and rough, granular or wispy colonies) and by gram assays and the three stains included in this study resulted in gram-positive. Massive qualitative determination of indole-acetic acid production has been used to select the most promising bacterial strains and three of them were selected for further characterization.

\section{Determination of indole-acetic acid production}

The three selected strains displayed remarkable high level of IAA synthesis in the absence and presence of L-tryptophan. In the absence of tryptophan the three strains showed similar IAA production between $0.915 \mu \mathrm{g} / \mathrm{ml}$ to $0.972 \mu \mathrm{g} / \mathrm{ml}$. In the presence of $0,50,100,150,200,500$ and $1000 \mu \mathrm{g} / \mathrm{ml}$ of up to 7 times in IAA production were observed, compared with the level obtained in absence of tryptophan but no differences between bacterial strain strains were observed (Table 1).

\section{Identification of selected bacterial isolates}

We identified the isolates by partially sequencing of the PCR amplified 16s rRNA gene followed by comparison against the NCBI sequence database using the BLASTN algorithm [49]. We compared the sequences of amplified $16 \mathrm{~S}$ fragment of selected strain with the $16 \mathrm{~S}$ sequences from other strains isolated from the same place to observe if they have common phylogeny (Figure 1). The three isolates were classified as Pseudomonas variovencis strain XiU1297, Luteibacter sp. Strain XiU129 and Acinetobacter iwoffii XiU12138.

\section{ACC deaminase activity}

The three selected isolates were screened for ACC deaminase based on the enrichment method, where ACC play the role of sole nitrogen source. The ACC deaminase enzyme activity was assayed under both non-stress and drought stress conditions by quantifying the amount of a-ketobutyrate produced during the deamination of ACC by the enzyme ACC deaminase. The strains grew well on MM9 medium with either ACC or ammonium sulfate serving as the sole nitrogen source. To simulate drought stress condition the MM9 medium supplemented with PEG 6000. The highest amount of ACC deaminase activity (4.97$5.35 \mu \mathrm{M} / \mathrm{mg}$ protein/h of $\alpha$-ketobutyrate) was obtained under non-stress condition whereas the lowest activity ( 3.17 to $3.35 \mu \mathrm{M} / \mathrm{mg}$ protein/h of a-ketobutyrate) was obtained under induced drought stress condition (Table 2). The same levels of ACC deaminase activity with where obtained for all strains, but well correlated differences between

\begin{tabular}{|c|c|c|c|c|c|c|c|c|c|c|c|c|c|}
\hline \multirow[t]{2}{*}{ Serial Number } & \multirow[t]{2}{*}{ Bacterial Strain } & \multirow[b]{2}{*}{0} & \multirow[b]{2}{*}{$\boldsymbol{\sigma}$} & \multicolumn{9}{|c|}{ IAA production $(\mu \mathrm{g} / \mathrm{ml})$ at different tryptophan concentrations $(\mu \mathrm{g} / \mathrm{ml})$} & \multirow[b]{2}{*}{$\boldsymbol{\sigma}$} \\
\hline & & & & 50 & $\sigma$ & 150 & $\sigma$ & 300 & $\sigma$ & 400 & $\sigma$ & 500 & \\
\hline XiU1292 & Luteibacter sp. & 0.458 & 0.15 & 1,67 & 0.21 & 3.52 & 0.15 & 7.46 & 0.40 & 12.65 & 0.29 & 25.34 & 0,14 \\
\hline XiU1297 & Pseudomonas vranovencis & 0.522 & 0.21 & 1.83 & 0.35 & 3.28 & 0.23 & 7.02 & 0.28 & 12.22 & 0.31 & 22.62 & 0.25 \\
\hline XiU12138 & Acinetobacter iwoffii & 0.475 & 0.17 & 172 & 0.27 & 3.35 & 0.25 & 6.97 & 0.32 & 13.01 & 0.24 & 23.09 & 0.22 \\
\hline
\end{tabular}
non-stressed and drought stress conditions have been observed.

The values represent the mean of three independent experiments, $n: 3, \sigma:$ Standard Deviation

Table 1: Quantitative determination of IAA production at different tryptophanconcentration. 
Citation: Colli JG, de la Riva de la Riva GA, Vargas-Sámano CD, Pérez-Machado G, Agüero-Chapin G (2017) Plant Growth Promoting Bacteria Isolated From a Mexican Natural Ecosystem Induce Water Stress Resistance in Maize and Sorghum Plants. J Microb Biochem Technol 9:209-219. doi: 10.4172/1948-5948.1000367

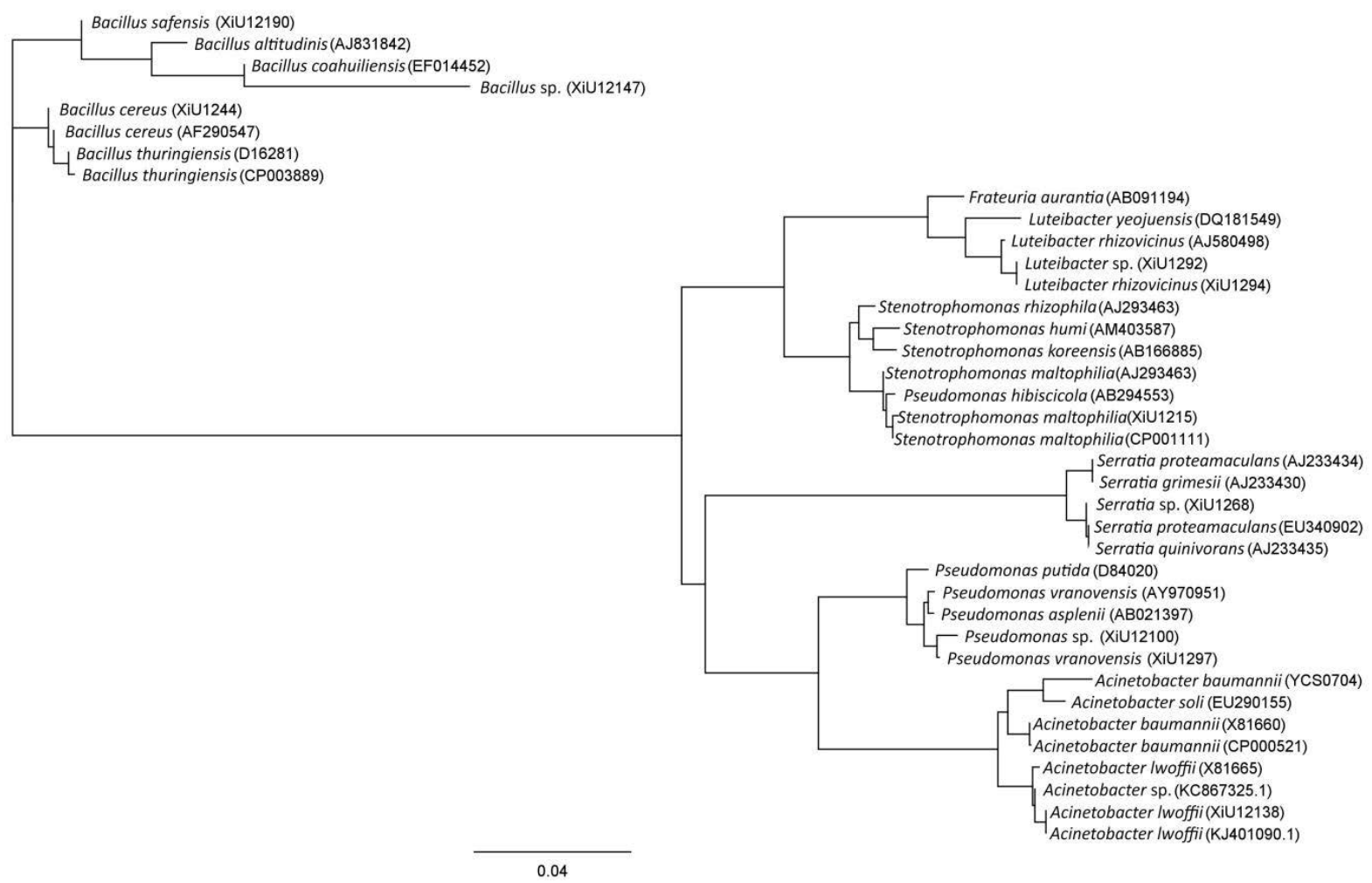

Figure 1: Phylogenetic relationships among selected bacterial strains isolated from Charco Azul using the 16s rRNA genes using the Neighbor-Joining method. The tree is drawn to scale, branch lengths represent the distances computed using the Kimura-2 parameters model and are expressed in units of number of base substitutions per site. The analysis involved 37 nucleotide sequences and was conducted in MEGA5.

\begin{tabular}{|c|c|c|c|c|c|}
\hline \multirow[t]{2}{*}{ Serial Number } & \multirow[t]{2}{*}{ Bacterial Strain } & \multicolumn{4}{|c|}{ AAC deaminase activity $(\mu \mathrm{M} / \mathrm{mg}$ protein $/ \mathrm{h}$ of $\alpha$-ketobutyrate) } \\
\hline & & Non-stress condition & $\sigma$ & Drought conditions & $\sigma$ \\
\hline XiU1292 & Luteibacter sp. & 5.35 & 0.21 & 3.23 & 0.19 \\
\hline XiU1297 & Pseudomonas vranovencis & 4.97 & 0.19 & 3.18 & 0.21 \\
\hline XiU12138 & Acinetobacter iwoffii & 5.15 & 0.20 & 3.27 & 0.25 \\
\hline
\end{tabular}

The values represent the mean of three independent experiments, $n: 3, \sigma:$ Standard Deviation

Table 2: ACC deaminase activity in bacterial strains under drought stresscondition.

\begin{tabular}{|c|c|c|c|c|c|c|c|c|}
\hline Serial Number & Bacterial Strain & $\begin{array}{c}16 S \\
\text { Identity }\end{array}$ & IAA & Siderophores & Cellulases & Chitinases & $\begin{array}{c}\text { Phosphate } \\
\text { Mobilization }\end{array}$ & $\begin{array}{c}\text { PHB } \\
\text { Production }\end{array}$ \\
\hline XiU1292 & Luteibacter sp. & $97 \%$ & $\mathrm{H}$ & $\mathrm{H}$ & $\mathrm{H}$ & L & $\mathrm{H}$ & L \\
\hline XiU1297 & Pseudomonas vranovencis & $100 \%$ & $\mathrm{H}$ & $\mathrm{H}$ & $\mathrm{L}$ & $M$ & $\mathrm{H}$ & $\mathrm{H}$ \\
\hline XiU12138 & Acinetobacter iwoffii & $100 \%$ & $\mathrm{H}$ & $\mathrm{L}$ & $\mathrm{L}$ & $\mathrm{H}$ & $\mathrm{L}$ & $\mathrm{L}$ \\
\hline
\end{tabular}

Table 3: Preliminary qualitative growth promoting and other traits exhibited by selected soil bacterial isolates during the qualitative screening test for different traits The relative strengths in each case were established by comparison of internal test control in each assayed traits and were classified in three groups: low (L), medium (M) and high $(\mathrm{H})$.

\section{Other biochemical traits}

The three strains have been assayed for other important metabolic activities: synthesis of siderophore, cellulase, chitinase, phosphate mobilization and biopolymer (PHB) production. The results of preliminary qualitative tests showed that Luteibacter sp. (XiU1292) had high level of siderophore production, as well as cellulase activity but low chitinase, phosphate mobilization and PHB polymer production. Pseudomonas vranovencis (XiU1297) exhibited highest level of IAA, siderophore, phosphate mobilization and PHB production a medium level of chitinase activity and lowest cellulase activity. Finally,
Acinetobacter iwoffii (XiU12138) presented high IAA production and chitinase activities and lower levels in the rest of assays (Table 3).

\section{Plant growth promotion and water stress resistance conferring by selected strains in maize and sorghum}

We evaluate the plant-growth and water stress resistance of three selected bacterial isolates on maize and sorghum. We selected these three bacteria for their high level of IAA production, but also for the other biochemical activities important for plant growth and health. Experimental results showed that bacteria strains promote growth in 
Citation: Colli JG, de la Riva de la Riva GA, Vargas-Sámano CD, Pérez-Machado G, Agüero-Chapin G (2017) Plant Growth Promoting Bacteria Isolated From a Mexican Natural Ecosystem Induce Water Stress Resistance in Maize and Sorghum Plants. J Microb Biochem Technol 9:209-219. doi: 10.4172/1948-5948.1000367

A
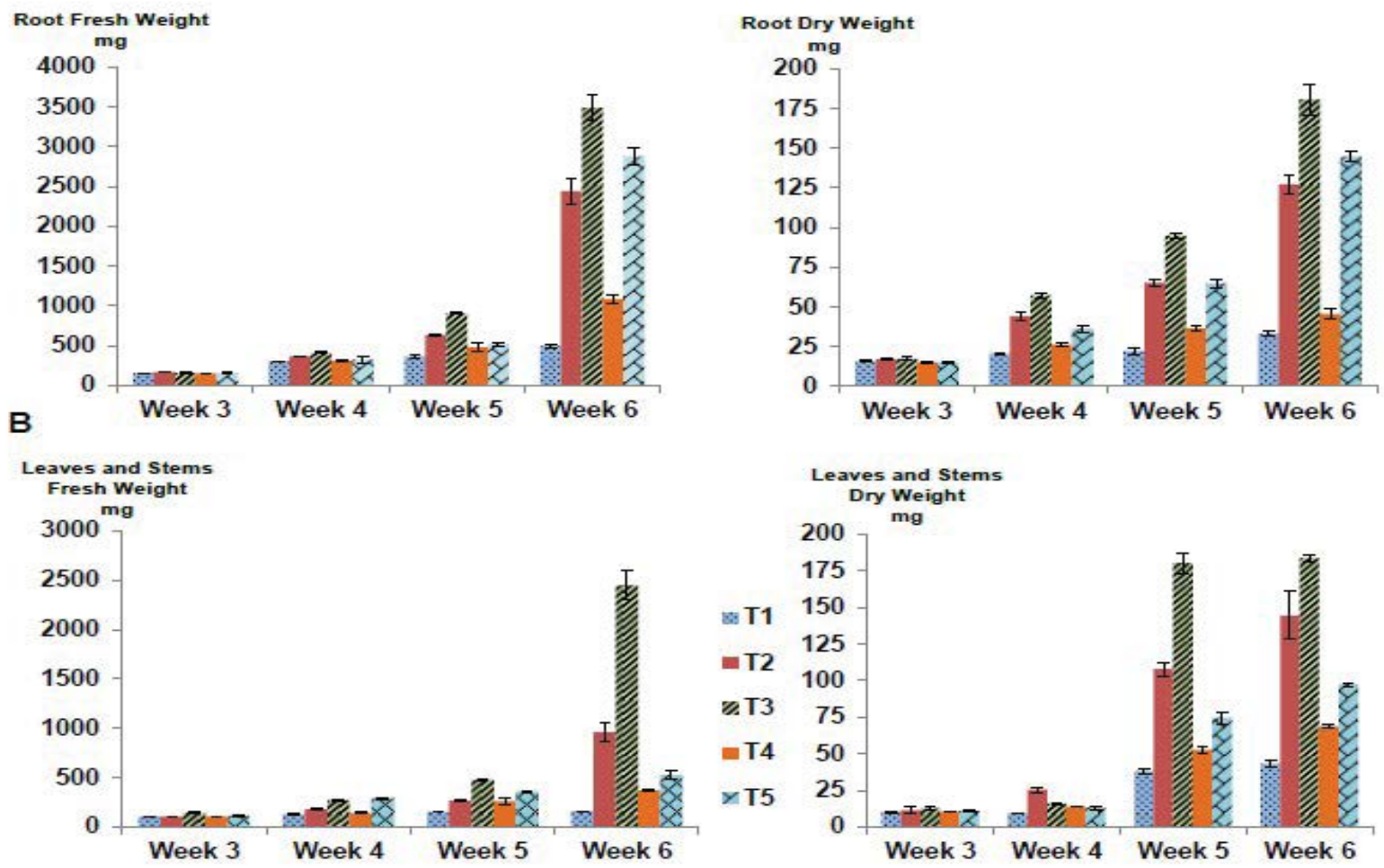

Figure 2: Effect of bacterial strains on roots development (A) and stems and leaves (B) in maize plants under water stress, evaluated by fresh and dry weight. Treatments: T1- No bacterial treatment, T2- Luteibacter sp. XiU1292, T3- Pseudomonas vranovencis XiU1297, T4- Acinetobacter iwoffii XiU12138, T5- Daily irrigated plant without bacterial treatment. Water irrigation was discontinued at the end of week 3 and restarted at the end of week 4.

\section{A}

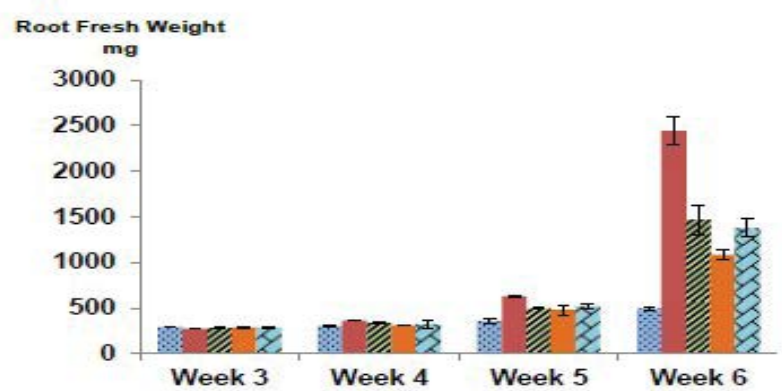

Root Dry Weight

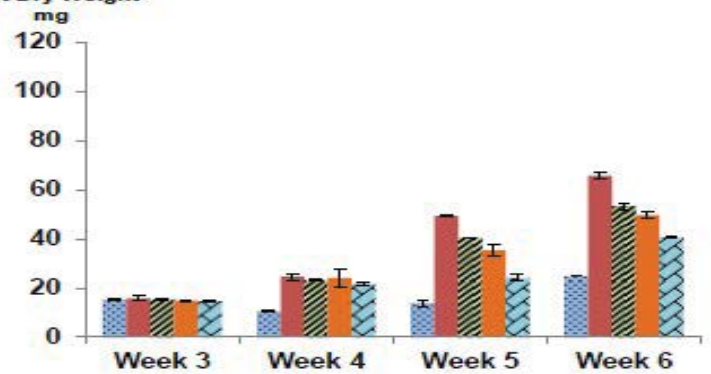

B

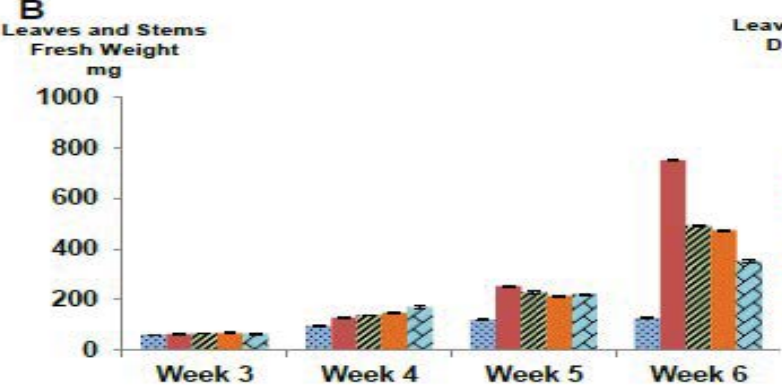

Leaves and Stem
Dry Weight
mg

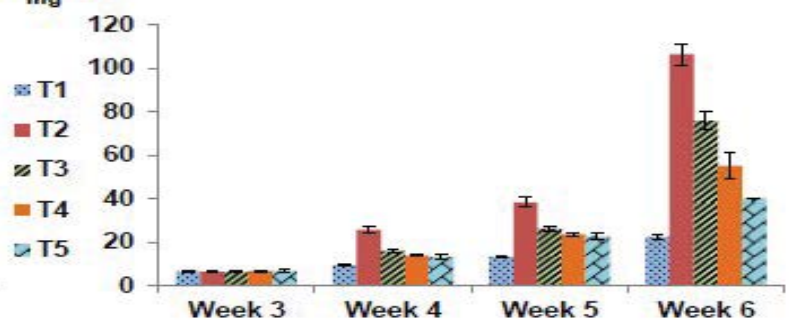

Figure 3: Effect of bacterial strains on roots development (A) and stems and leaves (B) in sorghum plants underwater stress, evaluated by fresh and dry weight. Treatments: T1-No bacterial treatment, T2- Luteibacter sp. XiU1292, T3- Pseudomonas vranovencis XiU1297, T4- Acinetobacter iwoffii XiU12138, T5- Daily irrigated plant without bacterial treatment. Water irrigation was discontinued at the end of week 3 and restarted at the end of week4. 
Citation: Colli JG, de la Riva de la Riva GA, Vargas-Sámano CD, Pérez-Machado G, Agüero-Chapin G (2017) Plant Growth Promoting Bacteria Isolated From a Mexican Natural Ecosystem Induce Water Stress Resistance in Maize and Sorghum Plants. J Microb Biochem Technol 9:209-219. doi: 10.4172/1948-5948.1000367

both plant species although all three shows relatively the same level of IAA production. In case of maize, the best growth-promotion was achieved by using $P$. variovencis XiU1297, followed by Luteibacter $s p$ XiU1292 and A. iwoffi XiU12138 (Figure 2). For sorghum, the highest growth-promotions were obtained by Luteibacter sp XiU1292 followed by $P$ variovencis XiU1297 and $A$. iwoffi XiU12138 (Figure 3). These results are well correlated with the water stress resistance and recovery patterns observed in the assayed plants as well as in RWC. In both crops, the highest RWC values were obtained for root developments regarding the achieved for stems and leaves.

\section{Prevalence of the bacterial inoculants}

We explore the dynamic prevalence of the inoculated strains during the water stress experiment. Previously we selected antibiotics allowing the positive selection of each isolated from the background as follows: Luteibacter sp. XiU1292 (Tetracycline $50 \mu \mathrm{g} / \mathrm{ml}$ ), P.vranovencis XiU1297 (Cephalexin $30 \mu \mathrm{g} / \mathrm{ml}$ ) and A. iwoffii XiU12138 (Kanamycin $30 \mu \mathrm{g} / \mathrm{ml}$ ). The used antibiotics allowed us to control other bacteria in the soil derived from the non-sterile experimental condition in greenhouse. Rhizosphere and bulk soil samples were collected at the started day, and at the weeks 3, 4, 5 and 6, after inoculation of plants from both crops with the PGPB. We quantify the number of UFC in soil and rizhosphere of both crops as described. The ability of isolates to colonize the rizhosphere of maize and sorghum as well as persistence in bulk soil was determined by plating and growing onto LB agar media supplemented with corresponding antibiotic The inoculants density (CFU counts/g RDM) was calculated logarithmically (Log10) in each step for both crops (Table 4). We observed that during the first two weeks the prevalence of bacterial CFU in bulk soil drops to less than $5 \times 10^{4} \mathrm{CFU}$ per gram of substrate, compared with initial concentration of $5 \times 10^{5} \mathrm{UFC} / \mathrm{g}$ soil. When water supply was suspended this tendency continues until water irrigation was restored at week four. Them, the prevalence continues stable until the end of experiment. In with rhizosphere, we failed to detect bacterial inoculants in weeks 2 . The inoculated bacteria were found in rhizosphere since the Week $3^{\text {rd }}$ until the week $4^{\text {th }}$. Then the bacterial prevalence was stabilized during the rest of experimental period.

\section{Discussion}

Soil is a dynamic ecological niche hosting living microorganisms that play an important role in processes essential for supporting plant development and the whole ecosystem. Most soils contain an enormous diversity of microorganisms: bacteria, actinomycetes, fungi, algae and protozoa. It has been reported that a typical gram of soil contains approximately $\sim 9 \times 10^{7}$ bacteria, $4 \times 10^{6}$ actinomycetes, $2 \times$ $10^{5}$ fungi, $3 \times 10^{4}$ algae, $5 \times 10^{3}$ protozoa and $3 \times 10^{1}$ nematodes although the numbers and types of these organisms and their dynamic vary greatly depending on the soil and climatic conditions [50]. The soil biota are also essential in decomposition and nutrient cycling processes, mineral and phosphorous mobilization, nitrogen fixation, plant adaptation to biotic and abiotic stress and growth promotion. The diversity of microbiota and the knowledge of its components, biochemical activities, biotic and abiotic interactions represent an opportunity to use soil microbial communities to increase crop productivity. From the bioprospected area Charco Azul, bacterial strains were isolated, morphologically characterized and integrated to Institutional Tissue and Culture Collection (ITCC). The majority of bacterial isolates were collected from rizhosphere, the small zone adjacent to plant roots where major microbial activity is concentrated and from aggregates of organic matter found in the bulk soil. The comparison of $16 \mathrm{~S}$ genes among selected bacterial strains isolated from Charco Azul show the phylogeny relationship. The three bacterial strains (L. sp strain XiU1292, P. variovencis strain XiU1297 and $A$. iwoffi strain XiU12138) were selected for evaluation on maize and sorghum plants showing that they producer plant growth regulators and have a consistent prevalence in the soil conditions of

\begin{tabular}{|c|c|c|c|c|c|c|c|c|c|c|c|}
\hline \multicolumn{12}{|l|}{ A. Maize } \\
\hline Bacterial Strain & Location & $\begin{array}{c}\text { Week } 2 \\
\text { (104) }\end{array}$ & $\sigma(104)$ & $\begin{array}{l}\text { Week } 3 \\
\text { (104) }\end{array}$ & $\sigma(104)$ & $\begin{array}{l}\text { Week } 4 \\
\text { (104) }\end{array}$ & $\sigma(104)$ & $\begin{array}{l}\text { Week } 5 \\
\text { (104) }\end{array}$ & $\sigma(104)$ & $\begin{array}{l}\text { Week } 6 \\
(104)\end{array}$ & $\sigma(104)$ \\
\hline \multirow[t]{2}{*}{$\begin{array}{l}\text { Luteibacter } \\
\text { sp. XiU1292 }\end{array}$} & $\begin{array}{l}\text { Rizhosphere CFU/ } \\
\text { gram RDM }\end{array}$ & 0.00 & 0.00 & 0.25 & 0.01 & 0.45 & 0.08 & 0.41 & 0.12 & 0.39 & 0.09 \\
\hline & Bulk CFU/g soil) & 4.91 & 0.15 & 3.45 & 0.09 & 3.56 & 0.31 & 3.50 & 0.28 & 3.52 & 0.24 \\
\hline \multirow{2}{*}{$\begin{array}{l}\text { Pseudomonas } \\
\text { vranovencis } \\
\text { XiU1297 }\end{array}$} & $\begin{array}{l}\text { Rizhosphere CFU/ } \\
\text { gram RDM }\end{array}$ & 0.00 & 0.00 & 0.28 & 0.07 & 0.55 & 0.09 & 0.51 & 0.09 & 0.57 & 0.12 \\
\hline & Bulk CFU/g soil) & 4.87 & 0.23 & 4.01 & 0.19 & 3.92 & 0.29 & 3.85 & 0.21 & 3.89 & 0.31 \\
\hline \multirow[t]{2}{*}{$\begin{array}{l}\text { Acinetobacter } \\
\text { iwoffii XiU12138 }\end{array}$} & $\begin{array}{l}\text { Rizhosphere CFU/ } \\
\text { gram RDM }\end{array}$ & 0.00 & 0.00 & 0.12 & 0.00 & 0.14 & 0.05 & 0.23 & 0.11 & 0.25 & 0.07 \\
\hline & Bulk CFU/g soil) & 4.95 & 0.31 & 3.25 & 0.25 & 3.34 & 0.21 & 3.43 & 0.26 & 3.44 & 0.29 \\
\hline \multicolumn{12}{|l|}{ B. Sorghum } \\
\hline \multirow[t]{3}{*}{ Bacterial Strain } & Location & $\begin{array}{l}\text { Week } 2 \\
\text { (104) }\end{array}$ & $\sigma(104)$ & $\begin{array}{l}\text { Week } 3 \\
\text { (104) }\end{array}$ & $\sigma(104)$ & $\begin{array}{l}\text { Week } 4 \\
\text { (104) }\end{array}$ & $\sigma(104)$ & $\begin{array}{l}\text { Week } 5 \\
\text { (104) }\end{array}$ & $\sigma(104)$ & $\begin{array}{l}\text { Week } 6 \\
\text { (104) }\end{array}$ & $\sigma(104)$ \\
\hline & $\begin{array}{l}\text { Rizhosphere CFU/ } \\
\text { gram RDM }\end{array}$ & 0.00 & 0.00 & 0.28 & 0.06 & 0.32 & 0.09 & 0.42 & 0.11 & 0.42 & 0.09 \\
\hline & Bulk CFU/g soil) & 4.89 & 0.23 & 3.55 & 0.19 & 3.75 & 0.16 & 3.80 & 0.24 & 3.79 & 0.12 \\
\hline \multirow{2}{*}{$\begin{array}{l}\text { Pseudomonas } \\
\text { vranovencis } \\
\text { XiU1297 }\end{array}$} & $\begin{array}{l}\text { Rizhosphere CFU/ } \\
\text { gram RDM }\end{array}$ & 0.00 & 0.00 & 0.13 & 0.08 & 0.25 & 0.05 & 0.24 & 0.04 & 0.29 & 0.06 \\
\hline & Bulk CFU/g soil) & 4.85 & 0.17 & 3.45 & 0.21 & 3.54 & 0.13 & 3.38 & 0.18 & 3.25 & 0.16 \\
\hline \multirow[t]{2}{*}{$\begin{array}{l}\text { Acinetobacter } \\
\text { iwoffii XiU12138 }\end{array}$} & $\begin{array}{l}\text { Rizhosphere CFU/ } \\
\text { gram RDM }\end{array}$ & 0.00 & 0.00 & 0.11 & 0.02 & 0.19 & 0.06 & 0.21 & 0.05 & 0.21 & 0.08 \\
\hline & Bulk CFU/g soil) & 4.94 & 0.25 & 3.29 & 0.31 & 3.25 & 0.23 & 3.31 & 0.18 & 3.19 & 0.21 \\
\hline
\end{tabular}

б: Standard Deviation. CFU/g RDM: Colony forming units per gram of root dry weight, $p \leq 0.05$

Table 4: Prevalence of bacteria in rizhosphere and bulk soil during greenhouse plant-PGPB interaction experiment. The starting bacterial concentration was $5 \times 10^{5} \mathrm{CFU} / \mathrm{g}$ soil in both crops. A: maize, B: sorghum 
the Bajío. They exhibit similar growth patterns during their cultivation in both solid and liquid LB medium (data not shown). These similarities were desirables to study their beneficial effect on maize and sorghum plants together with their plant growth promotion effects, resistance to water stress and specific plant-bacteria interactions. Some differences among these strains were found in other activities, those differences could influence in the effects observed on plant growth. The IAA production determined on these three bacterial isolates showed no remarkable differences in IAA production with or without the presence of tryptophan. We observed similar tryptophan depend pattern in IAA production as reported previously by other authors which is relevant to mention since the ability of PGPB to produce IAA in the rhizosphere greatly depend on presence and abundance of precursors $[47,51,52]$. Ethylene, a plant hormone which is found in all higher plants, is an important modulator of plant growth and development and it acts as a key factor to adequate response of the plants to a wide range of stresses [53]. The role of ethylene in physiological plant development is evident in different tissue developments such as roots, stems, leaves, flowers and fruits [30]. In case of legumes this hormone modulates rhizobia nodulations rooting of cuttings and plant's interaction with beneficial fungi including mycorrhizal symbiosis [54-56]. Ethylene synthesis is affected by a number of different factors including temperature, light, gravity, nutrition, the general hormonal correlation in plant and wild range of abiotic and biotic stresses [57]. Generation of ethylene is liked by the consumption of 1-aminocyclopropane-1-carboxylate (ACC), a precursor of ethylene. The measure 1-aminocyclopropane-1carboxylate (ACC) deaminase activity is crucial to evaluate the bacterial trait involved in promoting plant growth. ACC deaminase is responsible for the cleavage of the plant ethylene precursor, ACC, into ammonia and a-ketobutyrate decreasing ACC levels and ethylene levels in plants. Comparing ACC deaminase activity of the three stains we observed similar pattern (Table 2), at the same level as reported by other authors [52]. This activity drop when plants are in drought stress condition. It has been suggested that reduction in ethylene production may improve plant cells by increasing membrane fluidity $[52,58]$ and by activating the expression of some abiotic-stress related genes that participate in conferring resistance during abiotic stress as water stress $[59,60]$. Although the IAA production is considered as the most important criterion to identified PGPB, other factors must be taken in account to explain the beneficial effect of bacteria on plant development, such as plant-microorganism interactions, the prevalence of applied bacterial strains in soil and the reduction of ethylene production [30,50]. Other traits that have been studied included synthesis of siderophore, cellulase, chitinase, phosphate mobilization and biopolymer (PHB) production (Table 3). These aspects are directly related to plant growth since they influence plant development and health. In case of siderophore production, highest production was detected for strain L. sp. XiU1292 and P. vranovencis XiU1297followed by the A. iwoffii XiU12138. All three strains were confronted to fungi Fusarium verticillioides, Fusarium solani and Rizoctonia solani, important pathogens of maize and sorghum and the three bacteria exhibited antifungal activity evidenced by growth inhibition zone against test fungi. We cannot distinguish a consistent differences between growth inhibition zone produced by this strain respect to the other two although in vitro assays distinguished lower siderophore production in case A. iwoffi XiU12138. Other antifungal factors may be present also in PGPB, like glucanase and chitinase activities or secondary metabolites synthesis. Combining siderophore and chitinase activities we found that A. iwoffii XiU12138 showed highest chitinase activity but lowest siderophore synthesis compared with L sp. XiU1292, that showed high siderophore but low chitinase activities and Pvranovencis XiU1297, that showed high siderophore but medium chitinase activities. However more detailed studies, including secondary metabolism synthesis, are required to define this matter. The antifungal activity in PGPB is important particularly because of its incidence in the plant health and production yields. Bacterial strains, which expressed siderophore, chitinase and glucanase activities, should be active against wide range of fungi, having glucanos and chitin in their cell wall composition. Phosphorus is one of the most important elements in plant nutrition, phosphate solubilization or mobilization is usually linked with Calcium. There are two main types of phosphorous in soil, organic and inorganic phosphates, largely present in insoluble forms that impact negatively in plant nutrition since insoluble forms could not be used for plant nutrition. Organic phosphates are an important but also immobilized form of phosphorous accounting 20 $80 \%$ of total soil phosphorous [61]. To make this important compounds available to plants, phosphate mobilization trait is an important characteristic toevaluate in all PGPB. In our case P.vranovencis XiU1297 showed highest phosphate mobilization activity "in vitro" than the other two strains that showed a low activity. The ability of PGPB to solubilize precipitated phosphates and to enhance phosphate availability to maize, sorghum and other crops represents another possible mechanism of plant growth promotion under field conditions. Infection and invasion of roots by bacteria requires degradation of plant cell walls, which might be an active process involving plant polymer degrading enzymes. Cellulase, as well as other activities, like pectinases, is often produced by phytopathogenic bacteria such as $P$. solanacearum and E. chrysanththemi which hydrolyses cellulose and pectin present in plant cell wall, allowing the pathogens to penetrate the plant tissues. In our experience cellulase and pectinases are actively secreted to the bulk soil helping to recycle plant debris such as fallen leaves, flowers and fruits [62]. In this study cellulose and pectinase activities of strains didn't affect the growth or health of the seedlings. Since our bacterial prevalence studies we consider that as soon as bacterial strains colonize the plant rhizosphere or become endophytic plant exudates as well as other members of endophytic or rhizospheric microbiota suppress the production of such enzymes. In our case a colonization processes were observed in both crops for all the three inoculated bacterial and the results of plant-PGPB experiment were well correlated with the prevalence of bacterial strains in both rhizosphere and bulk soil (Table 4). The biopolymer (PHB) production is anther trait that was also evaluated. The highest level was detected in case of P. vranovencis XiU1297. Synthesis of biopolymer by PGPB is frequently demerited as an important plant growth promotion because it is considered undirected factor. Many species of beneficial bacteria form micro colonies or biofilm. Bacterial surface components, such as PHB, in association with bacterial signals can be important in the process of biofilm formation and also in functionally and structurally supporting the diverse arrays in rhizospheric bacterial communities as well as helping its cohesion, bacterial activity and survival by forming bacterial aggregates [63]. The environment occupied by soil bacteria range from rhizosphere, a small layer rich in nutrient and plenty of bacteria exhibiting a wide range of biochemical activities, to the bulk soil, deficient in nitrogen, phosphates and water, among other important nutrients $[64,65]$. Another important aspect of biopolymers producing by PGPB is its role in bioaugmentation and bioremediation of impacted soils. Many industrial and agricultural activities during five hundreds year, but especially in the last forty years, have caused the significant increase in the concentration toxic residues and pollutants in environments in the Bajío regions and in the rest of the world. Together with mining, 
Citation: Colli JG, de la Riva de la Riva GA, Vargas-Sámano CD, Pérez-Machado G, Agüero-Chapin G (2017) Plant Growth Promoting Bacteria Isolated From a Mexican Natural Ecosystem Induce Water Stress Resistance in Maize and Sorghum Plants. J Microb Biochem Technol 9:209-219. doi: 10.4172/1948-5948.1000367

industrial, agriculture and other contaminants, there are also natural residues from volcanic geological origins of this region. Biopolymer producing PGPB can help the structure of microbiota to rhizosphere, drought resistance and augmentation in presence of soil contaminants [66,67]. Maize and sorghum plants were cultivate in soil conditions similar to agricultural lands of Bajío region but at greenhouse to manage the water supplied regime. The three bacterial strains added to these crops showed remarkable effect on their growth and water stress resistance, as it was previously reported [59,50]. However both plant species showed different responses to the treatments. In case of maize (Figure 2) better growth-promotion was obtained with $P$. variovencis XiU1297, followed by L. sp XiU1292 and A. iwoffi XiU12138. In case of sorghum (Figure 3), the highest growthpromotion was obtained with L. sp XiU1292, followed by P. variovencis XiU1297 and A. iwoffi XiU12138. These results correlated with the water stress resistance observed in assayed plants and the same tendency was observed when the RWC was determined (Figure 4). Our results are congruent with the observation reported in tomato plants [26]. Treated plants exposed to water stress condition showed enhanced resistance and recovery. The values of fresh and dry weights as well as the RWCs also explain such effects. The differences between the values of weights and RWC determined for roots and aerial part of the plant (stems and leaves) indicate a predominant root-specific effect by PGPB. However we also observed that PGPB can stimulate differentially plant growth depending on compatibility of plantmicroorganisminteractions. To explore the prevalence of each bacterial strain in maize and sorghum the recovery of bacteria from rizhosphere and bulk soil was done (Table 4). During the first two weeks, just after suspension of water supply, the UFC in bulk soil drops to less than $5 \times$ $10^{4}$ UFC per gram of soil, compared with initial concentration of $5 \times 10^{5}$ UFC/g soil $\left(1 \mathrm{~mL}\right.$ of $10^{8} \mathrm{CFU} / \mathrm{ml}: 200 \mathrm{~g}$ soil $=5 \times 10^{5} \mathrm{UFC} / \mathrm{g}$ soil $)$. The adaptation of bacteria to new conditions could be the factor explained the initial drop in UFC.

After induced drought stress the decreasing tendency continues but stabilization becomes when the water supply was restored at week 4. Bacterial prevalence continues stable to the end of experiment but some differences were observed between both plant species, revealing preferences in plant-bacteria interactions. Similar tendency was obtained when we analyzed bacterial colonization of maize and sorghum rhizosphere. We failed in the detection on bacterial inoculants in week 2 and just at week 3 after inoculation we began to recovery inoculated bacteria in rhizosphere, probably because the process of plant-bacteria interaction and rhizosphere colonization was in the initial steps. The relative amounts of bacteria in rhizosphere were well correlated with the differences found in bulk soil. The dynamic of the bacterial prevalence changed since drought stress was induced at week 2 . The prevalence of rhizospheric bacterial didn't show any decrease and continue growing after stabilization at week 4 , a tendency that continue during the rest of experiment. These results drive us to think that rhizosphere bacteria better survive the abiotic stress than those remaining in bulk soil and the presence of PGPB help the plant to support the water stress conditions. Plants under stress conditions are able to incorporate the soil nutrients and maintaining their health and physiological conditions when PGPB
A

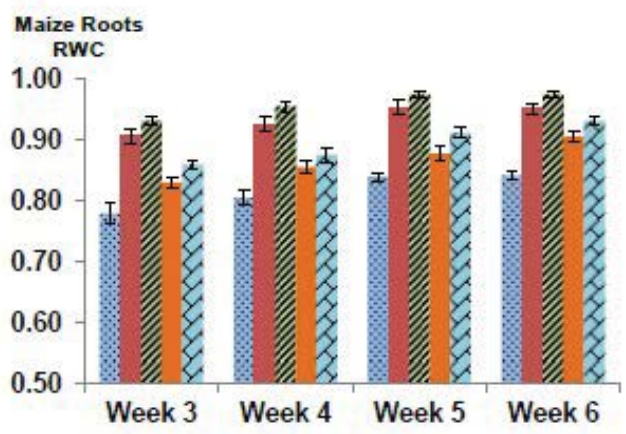

B

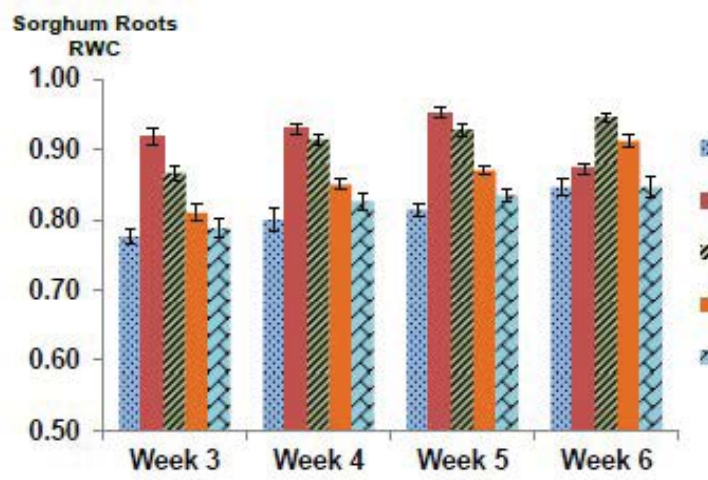

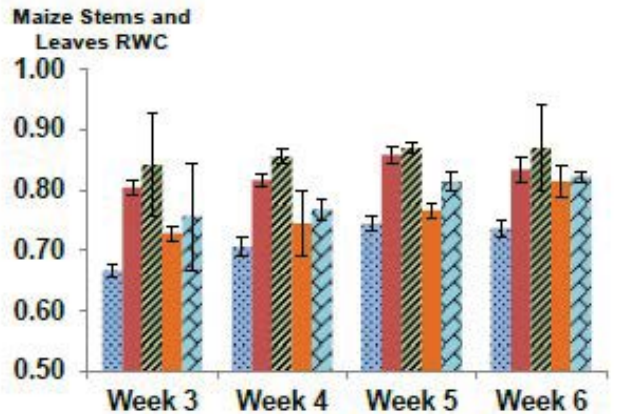

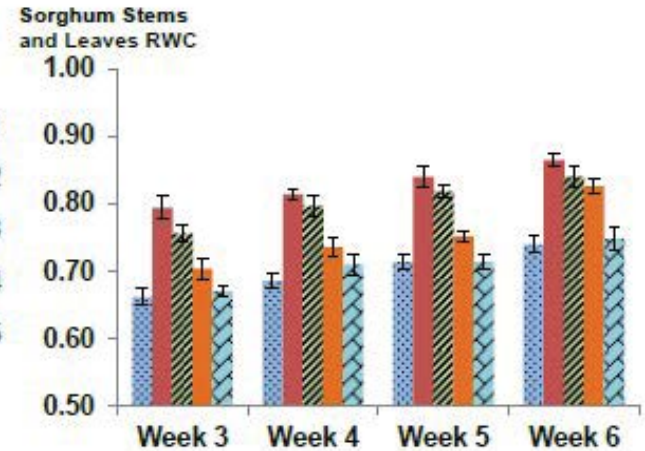

Figure 4: The effect of bacterial treatments on the relative water content (RWC) in maize and sorghum roots stems and leaves at greenhouse conditions. Treatments: T1-No bacterial treatment, T2- Luteibacter sp. XiU1292, T3- Pseudomonas vranovencis XiU1297, T4- Acinetobacter iwoffii XiU12138, T5- Daily irrigated plant without bacterial treatment. Water irrigation was discontinued at the end of week 3 and restarted at the end of week 4. 
Citation: Colli JG, de la Riva de la Riva GA, Vargas-Sámano CD, Pérez-Machado G, Agüero-Chapin G (2017) Plant Growth Promoting Bacteria Isolated From a Mexican Natural Ecosystem Induce Water Stress Resistance in Maize and Sorghum Plants. J Microb Biochem Technol 9:209-219. doi: 10.4172/1948-5948.1000367

displaying different beneficial factors for plant activities are present in the rhizosphere [68]. The plant-microbial community interactions plays confer beneficial effects to the plants in different environmental situations. These effects depend to the soil conditions and the specific characteristics of plants and the generation of specific changes in the plant-bacterial interaction, bacterial viability and prevalence in soil, the promotion of specific gene expression and the production of certain compounds influencing in plant behavior [69]. The soil characteristics influence to the microbiomes in the rhizosphere ant its activity [13]. Since bioprospected area is a temperate pine and oak forest $\left(16^{\circ} \mathrm{C}\right.$ average annual temperature), humid $(1200 \mathrm{~mm}$ annual rainfall) and the organic matter content are about $40 \%$. We need to evaluate the behavior and the effect of bacterial strains under soil and climatic conditions where the strains are projected to apply. We used maize and sorghum plants according to those existing in a semiwarm semi-humid region (700 $\mathrm{mm}$ annual rainfall), chernozem (black lands) soil type. Concerning the water stress resistance, it has been reported that bacterial RNA chaperones confer abiotic stress tolerance on plants and improved the grain yield in maize under water limited conditions [70-72].

\section{Conclusion}

Diversity of factors acts in the global effect of PGPB to plant development and this reveal the need of direct evaluation in crops before the bacterial application. The mechanism underlying the stimulation of overall plant performance mediated by PGPB in different situations is still an active research field due to its complexity. The selected strains differentially promoted plant development in maize and sorghum. P.vranovencis XiU1297 acts better in maize while the bacteria L. sp. XiU1292 does it better in sorghum. These abilities complement each other and conceive these strains suitable to integrate a bacterial consortium for application in agriculture together with other bacterial isolates. The absence of antagonism among bacterial strains selected as the consortium components were already assayed within these and other PGPB-bacteria, complementing different biological activities and environmental behaviors to conform different bacterial consortium suitable to use in different crops. The conformation of beneficial microbial consortia and its application contributes to the development of sustainable agriculture.

\section{Acknowledgement}

This research project is supported by grants from Instituto Tecnológico Superior de Irapuato (ITESI) and Tecnológico Nacional de México at Secretary of Public Education (SEP) of Federal Government of México (ITESI/TNM/PRODED/ SEP-ITESI-CA5/2013). GACH acknowledges the Portuguese Fundação para a Ciência e a Tecnologia (FCT) for financial support (SFRH/BPD/92978/2013). CDVS received a fellowship from Programa Verano de la Ciencia/Región Centro/2013CONACYT-México.

\section{References}

1. Farmer T (2005) A definitive, rapid alternative to the gram stain assay. Rapid Microbiology Newsletter 3: 2-3.

2. Gamalero E, Berta G, Massa N, Glick BR, Lingua G (2008) Synergistic interactions between the acc deaminase- producing bacterium Pseudomonas putida uw4 and the am fungus Gigaspora rosea positively affect cucumber plant growth. FEMS Microbiol Ecol 64: 459467

3. Montero-Calasanz MC, Santamaría C, Albareda M, Daza A, Duan J, et al. (2013) Rooting induction of semi-hardwood olive cuttings by several auxinproducing bacteria. Span J Agric Res 11:146154.

4. Dekwer D, Hempel DC (1999) Microaerophilic production of alginate by Azotobacter vinelandii. Von der Gemeinsamen Naturwissenscha ftlichen, Fakultat der Technischen UN. Carolo-Wilhelmina zu Braunschweig, Edited byWael Sabra, aus Alexandria, Agypten. 37-54.
5. Wensing A, Braun SD, Büttner P, Expert D, Völksch B, et al. (2010) Impac of siderophore production by Pseudomonas syringae pv. syringae $22 \mathrm{~d} / 93$ on epiphytic fitness and biocontrol activity against Pseudomonas syringae pv. glycinea 1a/96. Appl. Environ Microbiol 76: 2704-2711.

6. Morris RM, Vergin KL, Cho JC, Rappé MS, Carlson CA, et al. (2005) Temporal and spatial response of bacterioplankton lineages to annual convective overturn at the Bermuda's Atlantic time-series study site. Limnol Oceanogr 50: 16871696.

7. Yang L, Wang Y, Song J, Zhao W, He X, et al. (2011) Promotion of plant growth and in situ degradation of phenol by an engineered Pseudomonas fluorescens strain in different contaminated environments. Soil Biol Biochem 43: 915-922.

8. Silva-Stenico ME, Pacheco FT, Carrilho JL, Tsai SM (2005) Growth and siderophore production of Xylella fastidiosa under iron-limited conditions. Microbiol Res 160: 429-436.

9. Penrose DM, Glick BR (2003) Methods for isolating and characterizing ACC deaminase-containing plant growth promoting rhizobacteria. Physiol Plant 118 : 1015.

10. Antoun H, Kloepper JW (2001) Plant Growth promoting rhizobacteria. In Brenner S and Miller JH (eds). Genet Mol Biol:1477-1480.

11. Bueé M, Reich M, Murat C, Morin E, Nilsson RH, et al. (2009) 454 Pyrosequencing analyses of forest soils reveal an unexpectedly high fungal diversity. New Phytol 184: 449456.

12. Janssen $\mathrm{PH}$ (2006) Identifying the dominant soil bacterial taxa in libraries of 16S rRNA and 16S rRNA genes. Appl Environ Microbiol 72: 17191728.

13. Scheiter S, Ding GC, Heuer H, Neumann G, Sandmann M, et al. (2014) Effect of the soil type on the microbiome in the rhizosphere of field-grown lettuce. Front Microbiol 5: 1-14

14. Honma M, Shimomura T (1978) Metabolism of 1-aminocyclopropane-1carboxylic acid. Agri Biol Chem 42: 1825-1831.

15. Bashan LE, Hernandez JP, Bashan Y (2012) The potential contribution of plant growth promoting bacteria to reduce environmental degradation a comprehensive evaluation. Appl. Soil Ecol 61: 171-189.

16. Calvo P, Ormeño-Orrillo E, Martínez-Romero E, Zúñiga D (2010) Characterization of Bacillus isolates of potato rhizosphere from Andean soils of Peru and their potential PGPR characteristics. Braz J Microbiol 41: 899-906.

17. Bottini R, Cassán F, Piccoli P (2004) Gibberellin production by bacteria and its involvement in plant growth promotion and yield increase. Appl Microbio Biotechnol 65: 497-503.

18. Rudrappa T, Biedrzycki ML, Bais HP (2008) Causes and consequences of plant associated biofilms. FEMS Microbiol Ecol 64: 153-166.

19. Teather RM, Wood PJ (1982) Use of congo red-polysaccharide interactions in enumeration and characterization of cellulolytic bacteria from the bovine rumen. Appl Environ Microbiol 43: 777-780.

20. Shennan C (2008) Biotic interactions, ecological knowledge and agriculture Philos Trans R Soc Lond B 363: 717739.

21. Bakker P, Pieterse CMJ, Van Loon LC (2007) Induced systemic resistance by fluorescent Pseudomonas spp. Phytopathology 97: 239-243.

22. Stajkoviv O, Deloc D, Josic D, Kuzmanovic D, Rasulic N, et al. (2011) Improvement of common bean growth by co-inoculation with Rhizobium and plant growth-promoting bacteria. Romanian Biotechnol Lett 16: 5919-5926.

23. Gilbert JA, Field D, Swift P, Newbold L, Oliver A (2009) The seasonal structure of microbial communities in the western English channel. Environ Microbiol 11: 3132-3139.

24. Smith KP, Goodman RM (2000) Host variation for interactions with beneficial plant-associatedmicrobes. Ann Rev Phytopathol 37: 473-491.

25. Weisburg WG, Barns SM, Pelletier DA, Lane DJ (1991) 16S ribosomal DNA amplification for phylogenetic study. J Bacteriol 173: 697-703.

26. Kloepper JW, Lifshitz R, Zablotowicz RM (1989) Free-living bacterial inocula for enhancing crop productivity. Trends Biotechnol 7: 39-44.

27. Schwyn B, Neilands JB (1987) Universal chemical assay for the detection and determination of siderophores. Anal Biochem 160: 47-56. 
Citation: Colli JG, de la Riva de la Riva GA, Vargas-Sámano CD, Pérez-Machado G, Agüero-Chapin G (2017) Plant Growth Promoting Bacteria Isolated From a Mexican Natural Ecosystem Induce Water Stress Resistance in Maize and Sorghum Plants. J Microb Biochem Technol 9:209-219. doi: 10.4172/1948-5948.1000367

28. Fouilland E, Mostajir B (2010) Revisited phytoplanktonic carbon dependency of heterotrophic bacteria in freshwaters, transitional, coastal and oceanic waters FEMS Microbiol Ecol 73: 419-429.

29. Freitas JR, Banerjee MR, Germida JJ (1997) Phosphate-solubilizing rhizobacteria enhance the growth and yield but not phosphorus uptake of canola (Brassica napus L). Biol Fertil Soils 36:842-855.

30. Glick BR (2014) Bacteria with ACC deaminase can promote plant growth and help to feed the world. Microbiol Res 169: 30-39.

31. Kiyosue K, Yamaguchi K, Shinozaki K (1994) ERD15, a cDNA for dehydration induced gene from Arabidopsis thaliana. Plant Physiol 106: 1707-1712.

32. Menmood Z, Ahmad I, Mohammad F, Ahmad S (1999) Indian medicinal plants a potential source of anticandidal drug. Pharm Biol 37: 237-242.

33. Dodd J, Boddington L, Rodriguez A, Gonzalez-Chavez C, Mansur I (2000) Mycelium of Arbuscular Mycorrhizal fungi (AMF) from different genera: form, function and detection. Plant Soil 226: 131-151.

34. Salamone E, Hynes R, Nelson L (2001) Cytokinin production by plant growth promoting rhizobacteria and selected mutants. Can J of Microbiol 47: 404-411.

35. Glick BR, Bashan Y (1997) Genetic manipulation of plant growth promoting bacteria to enhance biocontrol of fungal phytopatogens. Biotechnol Adv 15: 353-378.

36. Van Loon LC, Geraats BPJ, Linthorst HJM (2006) Ethylene as a modulator of disease resistance in plants. Trends Plant Sci 11:184911.

37. Goodlass G, Smith KA (1979) Effects of ethylene on root extension of pea (Pisum sativum L.) and white clover (Trifolium repens L). Plant Soil 51:387-395.

38. O'Donnell AG, Seasman M, Macrae I, Waite I, Davies JT (2001) Plants and fertilizers as drivers of change in microbial community structure and function in soils. Plant Soil 232: 135-145.

39. Schoenborn L, Yates P, Grinton B, Hugenholtz P, Janssen P (2004) Liquid serial dilution is inferior to solid media for isolation of cultures representative of the phylum-level diversity of soil bacteria. Appl Environ Microbiol 70: 4363-4366.

40. Siddiqui ZA (2006) PGPR: Prospective biocontrol agents for plant pathogens. In: Siddiqui Z.A. (ed) Biocontrol and biofertilization. Springer, Amsterdam, pp: 111-142.

41. McClelland R (2001) Gram's Stain: the Key to Microbiology. Med Lab Obs 2001: 20-31.

42. Sun L, Wu J, Luo M, Wang X, Pan M, et al. (2011) Diversity oriented design of various benzophenone derivatives and their in vitro antifungal and antibacterial activities. Molecules 16: 9739-9754.

43. Pimentel MR, Molina G, Dionísio AP, Maróstica MR, Pastore GM (2011) The use of endophytes to obtain bioactive compounds and their application in biotransformation process. Biotechnol Res Int 2011: 1-11.

44. Borah B, Thahur PS, Nigam JN (2002) The influence of nutritional and environmental conditions on the accumulation of poly- $\beta$-hydroxybutyrate in Bacillus mycoides RLJ B-017. J Appl Microbiol 92: 776-783.

45. Kloepper JW, Reddt MS, Rodríguez-Kabana R, Kenney DS, Kokalis-Burelle $\mathrm{N}$, et al. (2004) Application for rhizhobacteria, transplant production and yield enhancement. Acta Horticult 631: 217-229.

46. Compant S, Clement C, Sessitsch A (2010) Plant growth promoting bacteria in the rhizo- and endosphere of plants: Thwir role, colonization, mechanisms involved and prospect for utilization. Soil Biol Biochem 42: 669-678.

47. Mandeep SG, Parinita A, Baburao K, Rachna P (2013) Colonization and plan growth promotion of sorghum seedlings by endorhizospheric Serratia sp. Acta Biologica Indica 2: 343-352.

48. Sawar M, Kremer RJ (1995) Determination of bacterially derived auxins using a microplate method. Lett Appl Microbiol 20: 282285

49. Altschul SF, Madden TM, Schäffer AA, Zhang J, Zhang Z, et al. (1997) Gapped BLAST and PSI-BLAST: A new generation of protein database search programs. Nucl Acids Res 25: 3389-3402.

50. Glick BR (2012) Plant growth-promoting bacteria: Mechanisms and applications. Scientifica Article ID 963401: 15

51. Ahmad F, Ahmad I, Khan MS (2008) Screening of free-living rhizospheric bacteria for their multiple plant growth promoting activities. Microbiol Res 163 173-181.
52. Rachmania NM, Mahagiani I, Amaryllis A Santoso S, Rusmana I (2010) Chitinolytic bacteria isolated from chili rhizosphere: Chitinase characterization and its application as biocontrol for whitefly (Bemisia tabaci Genn.). Amer J Agri Biol Sci 5: 430-435.

53. Abeles FB, Morgan PW, Saltveit ME (1992) Ethylene in plant biology. 2nd ed.: Academic Press; New York

54. Glickmann E, Dessaux Y (1995) A critical examination of the specificity of the Salkowski reagent for indolic compounds produced by phytopathogenic bacteria. Appl Environ Microbiol 61 793-796.

55. Milagres A, Machuca A, Napoleão D (1999) Detection of siderophore production from several fungi and bacteria by a modification of chrome azurol S (CAS) agar plate assay. J Microbiol Methods 37: 1-6.

56. Frommel MI, Nowak J, Lazarovits G (1993) Treatment of potato tubers with growth promoting Pseudomonas ssp: Plant growth responses and bacterium distribution in the rhizosphere. Plant Soil 150: 51-60.

57. Van der Mortel M, Halverson LJ (2004) Cell envelope components contributing to biofilm growth and survival of Pseudomonas putida in low water content habitats. Mol Microbiol 52: 735-750.

58. Ahemadet M, Kibret M (2014) Mechanisms and applications of plant growth promoting rhizobacteria: Current perspective. J King Saud Uni Sci 26: 1-20.

59. Paolo C, Dave W, Robert JB, Don CA, Jay H, et al. (1993) Bacterial RNA chaperones confer abiotic stress tolerance in plants and improved grain yield in maize under water-limited conditions. Plant Physiol 147: 446-455.

60. Katarzyna H, Baum C (2014) Application of microorganisms in bioremediation of environment from heavy metals. Environ Deter Human Heal, pp: 215-227.

61. Reetha S, Bhuvaneswari G, Thamizhiniyan P, Ravi MT (2014) Isolation of indole acetic acid (IAA) producing rhizobacteria of Pseudomonas fluorescens and Bacillus subtilis and enhance growth of onion (Allim cepa L.). Int J Cur Microbiol App Sci 3: 568-574.

62. Law JH, Slepecky RA (1961) Assay of Poly- $\beta$-hydroxyburyric acid. J Bacteriol 82: $33-36$

63. Bogino PC, Oliva MM, Sorroche FG, Giordano W (2013) The role of bacteria biofilms and surface components in plant bacterial associations. Int $\mathrm{J}$ Mol Sci14: 15838-15859.

64. Rodríguez H, Fraga R, González T, Bashan Y (2006) Genetics of phosphate solubilization and its potential applications for plant growth promoting bacteria. Plant Soil 287: 15-21.

65. Tian F, Ding Y, Zhu H, Yao L, Du Y (2009) Genetic diversity of siderophore producing bacteria of tobacco rhizosphere. Braz J Microbiol 40: 276-284.

66. Pérez-García O, Pérez-García A, Diego-Romero D (2011) Plant protection and growth stimulation by microorganisms: Biotechnological applications of Bacilli in agriculture. Curr Opin Biotechnol 22: 187-193.

67. Wright SF, Upadhyaya A (1998) A survey of soils for aggregate stability and glomalin, a glycoprotein produced by hyphae of arbuscular mycorrhizal fungi. Plant Soil 198: 97-107.

68. Shaukat K, Affrasayab S, Hasnain S (2006) Growth responses of Triticum aestivum to pant growth promoting rizhobacteria used as biofertilizer. Res Microbiol 1: 330-338.

69. Cakmakci R, Donmez F, Aydin A, Sahin F (2006) Growth promotion of plants by growth promoting rhizobacteria under greenhouse and two different soil conditions. Soil Biol Biochem 38: 1482-1487.

70. Bänzinger S, Tobler N, Brandl H (2001) The formation of reserve polymers in Bacillus megaterium. Microbial Ecology Course, University of Zurich, WS 2001/02, Project Nr. 5

71. Mayak S, Tirosh T, Glick BR (2004) Plant growth promoting bacteria that confe resistance to water stress in tomatoes and peppers. Plant Sci 166: 525-530.

72. Yao H, He Z, Wilson MJ, Campbell CD (2000) Microbial biomass and community structure in a sequence of soils with increasing fertility and changing land use. Microb Ecol 40: 223-237.

This article was originally published in a special issue, Advances in Microbiology and Biołechnology handled by Editor(s). Dr. Gamil Sayed Gamil Zeedan, , National Research Center, Egypt 